\title{
New 'True' Socialism
}

\author{
DAVID BAXTER \\ University of Guelph
}

In her recent book entitled The Retreat From Class, Ellen Meiksins Wood suggests that the last decade has witnessed a revival of what she terms "'true' socialism." She points out that the principal feature of this 'true' socialism is the fact that it "prides itself on a rejection of Marxist 'economism' and 'class-reductionism,"' and as a result "has virtually excised class and class struggle from the socialist project." In consequence, Meiksins Wood continues, the "most distinctive feature of this current is the autonomization of idealogy and politics from any social basis, and more specifically from any class foundation."1

The Retreat From Class is constructed around a series of case studies each of which closely analyzes the way in which a prominent philosopher, sociologist or historian has sought to adopt and develop an approach of this kind.2 In each case, Meiksins Wood demonstrates how the attempt to 'autonomize' the instances of the ideological and state superstructures from any direct relation of determination by the economic infrastructure, is complemented by an argument which views these instances as in turn exercising a greater or lesser degree of determination over the economic base. The most important implication that may be drawn from these studies, she suggests, concerns how the school of 'true' socialism understands the working classes' role in the process of transition to a postcapitalist society. Briefly stated, by denying any necessary connection between the economic infrastructure of society and the instances of the ideological and state superstructures, these theoreticians effectively deny the Marxian view of the working class as the principal agents in the revolutionary struggle. Rather, because the development of a consciousness for social change no longer depends on the agent's direct relation to the economic infrastructure, it becomes possible to argue that the fight for a more 'just' and 'equitable' society may incorporate any group (for example, the women's movement, ecology groups, minority rights associations, and so forth) that expresses a desire to bring about changes to the current socio-economic formation. The traditional workers' movement for the attainment of a socialist mode of production is emptied of its class content and replaced by an eclectic struggle to implement, what

1 Ellen Meiksins Wood, The Retreat From Class (London: Verso, 1986) pp. 1-2.

2 Among the theorists discussed by Meiksins Wood are Nicos Poulantzas, Ernesto Laclau, Gareth Stedman Jones, Herbert Gintis and Samuel Bowles, Barry Hindess and Paul Hirst, Gavin Kitching. 
Marx pejoratively referred to as, a realm of "Human Rights." 3 In this way, Meiksins Wood notes, "the possession of strategic power and a capacity for collective action are not treated as essential criteria in identifying the agents of social transformation."4

New 'true' socialism has consistently sought to present itself as a radical critique of the traditional Marxian analysis of the contemporary capitalist socio-economic formation. As an intellectual project, however, it essentially founders on the inability of its practitioners to distinguish between important, but in the final instance merely 'cosmetic' changes to the capitalist formation, and deep 'structural' modifications which effect the very mode of functioning of that system. Our purpose in what follows will be to attempt to locate the ontological position adopted by this school of thought which has given rise to this failure of theoretical discrimination. Specifically, this position will be revealed through an analysis of Chantal Mouffe's attempt to reformulate the structure of the concepts that inform Marx's methodological interpretation of the social formation.

\section{The Intellectual Origins of New 'True' Socialism}

The immediate origin of this theory is found in the theoretical innovations that the French philosopher Louis Althusser proposed to the Marxian theory of historical materialism. In particular, Althusser questioned Marx's conceptualization of the structure of the social formation as presented in his 1859 'Preface' to $A$ Contribution to the Critique of Political Economy. This work had suggested that the explanatory logic of the social and historical process was constituted by a hierarchy of determinations (that is, a specified level of productive force development determining a corresponding economic infrastructure which, in turn, is conceived of as determining a corresponding ideological and state superstructure). For his part, however, Althusser insisted that the ultimate moment of determination in a social formation could only be understood as being exercised "in the last instance" by the economic

3 See the Manifesto of the Communist Party, Collected Works, vol. 6. p. 511. We are not, of course, suggesting that these groups and organizations do not have an important role to play in bringing about some form of postcapitalist society. What we do criticize is the manner in which the school of new 'true' socialism awards these groups the principal role in this process and, in addition, for its failure to specify what qualitative distinction exists between this struggle and traditional struggles directed towards the alleviation of the material conditions of existence that are created by the capitalist system. We shall return to this latter point in more detail below.

4 Meiksins Wood, p. 5. 
level.5 The various elements of the social formation (the economic instance, along with the instances of the state superstructure such as the 'political' and the 'ideological') are conceived to be "asymmetrically related but autonomous" with one specified instance of the superstructure understood as being dominant at any particular point in time.

The crucial feature of Althusser's analysis was the Engelsian point that in such a totality the economic instance could only be viewed as determinant "in the last instance," with the further non-Engelsian proviso that this moment in the process of determination will "never come." In other words, the mode of determination in the last instance by the economic level is never conceived as actually operative. Rather, the economic is understood as determining which other instance of the social formation (for example, the 'political' or the 'ideological') will function as the principal mode of determination. It is further suggested that this operative instance of determination may change and vary over time according to the specific situation of "overdetermination" which exists in the social formation. 6 In short, Althusser's presentation of the structure of the social formation (which he terms a "structure in dominance") seeks to deny the Marxian thesis of a hierarchy of determinations that is rooted in the development of the productive forces. Instead, a theory is proposed which is directed towards awarding a greater or lesser degree of "relative autonomy" to the instances of the state superstructure.7

From what source did Althusser derive this theory? On his own explicit admission, the argument for a "structure in dominance" and, more particularly, for the relative autonomy of the instances of the ideological and state superstructure, originates in a letter sent by Engels to Joseph

5L. Althusser, For Marx (London: Allen Lane, The Penguin Press, 1969) PP. 106-107, 111-113, 205.

Marx's hierarchical theory of social determination is explained and illustrated in J. McMurtry, The Structure of Marx's World-View (Princeton: Princeton University Press, 1978) and G. A. Cohen, Karl Marx's Theory of History: A Defence (Princeton: Princeton University Press, 1978).

6 For Althusser's explanation of how this concept applies to Lenin's analysis of the Bolshevik revolution see, For Marx, pp. 97-101.

7 The whole rationale of this approach was based on the belief that it would improve the explanatory power of the theory of historical materialism by avoiding the type of rigid reductionism that Marx's own account had come to be associated with. We cannot, at this juncture enter into a detailed consideration of this claim. We shall simply point out that neither Althusser nor any of this followers have ever seen fit to explain analytically the theoretical principles upon which their claim rests. 
Bloch shortly before the former's death. ${ }^{8}$ In this letter, Engels suggested that the "production and reproduction of real life" was always to be viewed as the ultimate determining factor in the constitution of a particular social formation. He added, however, that it would be a mistake to conceive of this factor as exercising its mode of determination in, as it were, 'isolation.' On the contrary, Engels pointed out that other superstructural instances ("political, juristic, philosophical theories, religious views") must also be understood as acting to promote "their influence upon the course of the historical struggles and in many cases preponderate in determining their form." It was Engels' considered opinion, in other words, that the contours of the form assumed by the socio-economic formation were to an appreciable degree determined by the various instances of the state superstructure.

Despite this emphasis on the importance of the role that is played by superstructural instances, it must be stressed that Engels did not deny the ultimate, direct influence of an operative economic infrastructure. The fact that individual superstructural instances have historically come to play a major or "preponderate" role in the constitution of specific social formations, is not to be interpreted as contravening the ordering of determining hierarchies proposed by Marx. In the 'Preface,' the latter had made it quite clear that the explanatory logic of any social formation is primarily based on the fact that a specified level of productive force development determines a corresponding set of social relations of production. In turn, these relations determine the instances of a corresponding ideological and state superstructure. As Marx's many instances of social and historical analyses make clear, however, such a hierarchical ordering also entails the possibility that in any given set of circumstances the instances of the superstructure may well exercise a powerful reciprocal determination over the economic infrastructure.9

The entire purpose of Engels' letter was to point out the possibility of such relations of reciprocal determination existing in the concrete reality of specific social formations. The letter is intended as a refutation of the position adopted by those 'Marxists' who had interpreted Marx's theory as suggesting that the instances of the state superstructure were 'uniquely' or 'strictly' determined by the economic infrastructure.10 At the same time, however, this entire process of reciprocal determination could only be

8 Engels' letter to Joseph Bloch, 21st September 1890, Selected Correspondence (Moscow: Foreign Languages Publishing House, n.d.) pp. 498-499.

9 See, for example, Marx's, The Eighteenth Brumaire of Louis Bonaparte, Collected Works, vol. 11.

10 Such an interpretation was advocated by some of Engels' contemporaries in the German Social-Democratic Party (SPD) and also, somewhat later, by Stalin. 
understood and explained on the basis of the hierarchy of determinations postulated in the 'Preface.' Both Marx and Engels believed that it was this hierarchy which rendered the possibility of a situation of reciprocal determination feasible in the first instance. We can therefore state that Althusser was correct to suggest that Engels emphasized the constitutive role that the instances of the state superstructure play in the creation of a particular social formation. Nevertheless, he was mistaken to go on to imply that the latter ever denied that these instances were subject to a primary determination by the economic infrastructure.

\section{Marx and Engels and the Methodological Totality}

If Althusser's error simply rested on a misreading of Engels' letter to Bloch, then there would be no obvious reason to conclude (as his followers who were later to form the nucleus of the school of new 'true' socialism did) that the working class must be displaced from their position as the principal agents in the process of the revolutionary transition to socialism. ${ }^{11}$ The problem, however, is more profound than this reaching down, as we shall discover, to the very roots of the Marxian methodological approach to the study of society. The context of this deeper problem is discovered, once again, in the course of a few remarks made by Engels. In his Anti-Dühring, during a brief discussion about the nature of the relationship between the moments of production and exchange in the methodological totality of the social formation, Engels commented that:

Political economy, in the widest sense, is the science of laws governing the production and exchange of the material means of subsistence in human society. Production and exchange are two different functions. Production can occur without exchange, exchange being necessarily only exchange of products - cannot occur without production. Each of these two social functions is subject to the action of external influences which are for the most part peculiar to it and for this reason each has also, for the most part, its own special laws. But on the other hand, they always determine and influence each other to such an extent that they might be

11 This is because in Althusser's account the working class are still reckoned to hold a unique position in capitalist society due to their special relation to the economic process. It is this connection which is denied by the advocates of the new 'true' socialism. 
termed the abscissa and ordinate of the economic curve. 12

A few pages later, after having introduced a consideration of the moment of distribution into this relationship, he noted:

Distribution, however, is not merely a passive result of production and exchange; it is an equally important reaction on both of these.13

Before commenting on Engels' purpose in making these remarks and prior to examining Althusser's interpretation of this issue, it will be helpful to recall how Marx himself viewed the relationship between the moments of the methodological totality. Near the beginning of the Grundrisse, Marx described how the distinctive human capacity for labor is constituted by the closely related, but nonetheless conceptually distinct, moments of production and consumption. He then indicated at some length the nature of the complicated hierarchy of mediations that exist between these two moments of the labor process and which eventually culminate in a relation in which each "creates the other in completing itself, and creates itself as the other." 14

The intricacies of Marx's argument for the structure of this hierarchy of mediations need not detain us here. What is important for our concern is that once he had completed this portion of his analysis, Marx immediately proceeded to award ontological primacy in this relationship to the moment of production. He stated that:

whether production and consumption are viewed as the activity of one or as many individuals, they appear in any case as moments of one process, in which production is the real point of departure and hence also the predominant moment. Consumption as urgency, as need, is itself an intrinsic moment of productive activity. But the latter is the point of departure for realization and hence also its predominant moment; it is the act through which the whole process again runs its course. The individual produces an object and, by consuming it, returns to himself, but returns as a productive and self-

12 F. Engels, Anti-Dühring (Moscow: Foreign Languages Publishing House, 1962) p. 163.

${ }^{13}$ Anti-Dühring, p. 165.

${ }^{14}$ K. Marx, Grundrisse (New York: Vintage Books, 1973), p. 93. 
reproducing individual. Consumption thus appears as a moment of production. 15

Marx further suggested that the moment of production was ontologically prior to the moment of distribution. This latter moment of the methodological totality acts, as it were, to intervene between the original moments of production and consumption in the labor process. He argued that this moment serves to determine the distribution of the instruments of production as well as the actual members of society throughout the different forms of the production process. In this way, it will determine what proportion of the material product created in the production process will be consumed by the various classes in society. ${ }^{16}$

By way of conclusion, Marx specifically noted that his argument was not to be taken as a denial of the fact that the precise form assumed by each existing moment of production had been determined and shaped by the particular historical paths of development previously undergone by the other moments of the methodological totality. 17 He suggested, however, that these historical paths of development could only be analyzed in terms of a prior process which was itself determined by the structure of a methodological totality in which the moment of production played the principal and dominant role. The reciprocal determination that is exercised by the subordinate moments of the methodological totality on the moment of production is only understandable, in Marx's opinion, on the basis of a hierarchical structure in which the moment of production always assumes the decisive role.

In the light of the attested fact that Marx read and approved Engels' arguments in the Anti-Düring, we shall presume to suppose that the account given of the relationship between the constitutive moments of the methodological totality in the latter work is consistent with the argument of the Grundrisse. This becomes readily apparent if we bear in mind that the argument in the Anti-Duhring for the structure of the methodological totality parallels the argument for the structure of the elements of the social formation in the letter to Bloch. Like Marx, Engels' emphasized how the moments of exchange and distribution exercise a significant reciprocal

15 Grundrisse, p. 94.

16 See, Grundrisse, p. 95.

17 For example, the mode of distribution of material wealth between the landowning aristocracy and the industrial bourgeoisie in early nineteenth century England sufficiently favored the latter that it permitted them to reproduce the productive mechanisms under their control on an ever expanding scale. If, on the contrary, the historically determined mode of distribution had favoured the aristocracy (as was the case in France), then the bourgeoisie would have found it a great deal more difficult to establish the basis of their economic power. 
determination on the moment of production in the methodological totality. At the same time, he never denied his friend's contention that the latter moment must always be understood, ontologically speaking, as exercising an ultimate, direct influence over the other moments of that totality. Engels' argument is to be read as an attempt to establish the nature of those relations of reciprocal determination which exist between these different moments. In addition, it is intended as a refutation of those theoreticians (such as Dühring) who aimed to introduce a re-ordering of this hierarchy such that the moments of distribution or exchange were to be considered as functioning ontologically prior to the moment of production. Just as their understanding of the mode of reciprocal determination awards primacy to the economic instance in the totality of the social formation, so similarly according to Marx and Engels, the moment of production is held to be the principally determining moment in the methodological totality.

\section{ALTHUSSER and the Methodological Totality}

Althusser's argument for the reformulation of the Marxian methodological totality exactly duplicates his previous interpretation of Engels' comments to Bloch. This reformulation occurs despite the fact that, in For Marx, Althusser correctly points out that the relationship between the moments of production, consumption, distribution and exchange cannot simply be understood as one of 'identity:' Indeed, he writes that within the "apparent circularity of conditioning," which Marx himself had described as constituting the structure of this totality, the moment of production is understood as ultimately determining. This circularity of conditioning, he concludes, can be theoretically described in terms of a "structure in dominance."18

If Althusser wishes to apply the concept of a structure in dominance to the methodological totality, however, then this would indicate that the moments of production, consumption, distribution and exchange are "asymmetrically related but autonomous," with one moment (consumption, distribution or exchange) conceived as dominant. Although he may claim that within this totality the moment of production will always be determining "in the last instance," we already know that for Althusser the operative determination of this "last instance" will never occur. On the contrary, if his use of theoretical concepts is to remain consistent in the context of his explanation of the structure of the methodological totality, then the moment of operative determination must be assigned to consumption, distribution or exchange. 19 Put another way,

18 See, For Marx, p. 206.

19 No doubt Althusser would also have us believe that the determining moment of the totality is to be considered variable according to the 
just as Althusser's description of the relationship between the various elements which go to form the social totality effectively abandons the Marxian thesis of a hierarchy of determinations so, similarly, his invocation of the concept of a "structure dominance," to describe the relationship between the moments of the methodological totality, effectively abandons the Marxian thesis of the ontological primacy of the moment of production in the analysis of the methodological totality.

\section{Mouffe and the Production Process}

Let us now consider how the theoreticians of the school of new 'true' socialism approach these issues. In an article entitled 'Working Class Hegemony and the Struggle for Socialism', Chantal Mouffe (one of the most vociferous proponents of new 'true' socialism) attempts to argue for a re-ordering of elements in the methodological totality on the basis of a "criticism of the postulate that labor-power is a commodity." We owe this latter 'discovery' to Herbert Gintis and Samuel Bowles who have "demonstrated convincingly" that, unlike all other commodities, the commodity of human labor-power can not be considered as a product of abstract labor. Rather, the production and reproduction of the commodity labor-power depends on the functioning of a quite distinct set of social relations from those which normally govern the mode of operation of the capitalist production process. In the instance of human labor-power, the governing relations are said to be found in the twin spheres of the 'family' and the 'state'.20

On the basis of this claim, Mouffe argues that unlike those other commodities (for instance, the instruments of labor) which form part of the capitalist production process and whose use-value is rendered effective by the fact that the capitalist has purchased them, the purchase of human labor-power is not by itself sufficient for the capitalist "to actually enjoy it." On the contrary, before any given amount of human labor-power will actually produce value, the capitalist entrepreneur must finds ways and means to compel that labor-power to produce value in the production process. Mouffe explains that:

a very large part of capitalist organization of labor is intelligible only in the light of the necessity of extracting labor from the labor-power that the capitalist has purchased. Production is thus not the locus of a unique

particular situation of "overdetermination" that exists in the methodological totality at any particular point in time.

20 Chantal Mouffe, 'Working Class Hegemony and the Struggle for Socialism', Studies in Political Economy no. 12. Fall 1973, p. 12. 
logic of an economic nature but is rather a terrain where antagonistic forces confront one another. ${ }^{21}$

The structure of the capitalist production process is to be understood as a determined outcome of the various struggles that have taken place between antagonistic classes "at the level of the labor process."

Mouffe then goes on to suggest that the form of these struggles, which are to be conceptually designated as being located in what she terms "relations in production," are themselves structured by the prevailing set of social relations of production. It is this combination of relations in production and social relations of production which "express the necessities of capital accumulation." Thus, according to Mouffe, the modifications which take place to the forms of capitalist domination in the production process are the direct result of those struggles which occur in the socially structured domain of "relations in production."22

Mouffe's argument might lead the unwary to suspect that the distinction between relations in production and relations of production represents a penetrating new insight into the analysis of the capitalist social formation. Theoretical innovation is not, however, one of the strengths of new 'true' socialism. Indeed, what Mouffe designates as a society's relations in production were previously identified by Marx (more precisely) as a set of 'technical' or 'work' relations of production. 23

For Marx, technological, work relations of production are located in that set of relations which bind together human labor-power, the instruments of labor and the objects of labor in the totality of a specific labor process. Technical co-operation is a necessary feature of every distinct socio-economic formation, although the precise historical form which this assumes will vary depending on what types of labor-power, instruments and objects of labor are combined. For example, during the epoch of capitalism, the imperatives that are imposed on human laborpower by the 'rhythm' of the instruments of labor demand a technological organization of the labor process in which a large number of discrete

21 Mouffe, pp. 12-13.

22 Mouffe (pp. 15-16) gives as an example of a modification to the form of capitalist domination the change from the extraction of 'absolute surplusvalue' (that is, when the bourgeoisie attempt to extract the maximum amount of surplus-value through the increase in the length of the working day), to the extraction of 'relative surplus-value' (that is, the attempt to extract the maximum amount of surplus-value through an increase in the intensity of the labor process). Mouffe does not explain why the working class should struggle so hard for the implementation of a more exploitative form of capitalist domination.

23 See K. Marx, Capital vol. 2. (Moscow: Progress Publishers, 1967) pp. 359 360 . 
labor-powers are concentrate together in a single workplace where they carry-out a series of consecutive and repetitive tasks.

From a Marxian perspective, the most crucial aspect of these technological, work relations of production (Mouffe's "relations in production") is that they form part of the productive forces. That is, these technical relations of production enjoy the same ontological status as, for instance, a society's instruments of production. Thus, like the latter, they form a necessary and required component of that process through which material use-values are created. Without the existence of a technological organization of the labor process there would simply be no means through which human labor-power, the instruments and objects of labor could be combined together to produce value in the structure of the capitalist production process.

It is for this reason that technological, work relations of production can not be said to admit, as such, of a terrain of class struggle. If members of the class of direct producers are to participate in the capitalist production process, then they may do so only in the framework of a set of technical relations of production which form the necessary context of that process. It is true that individual producers may refuse to enter into this framework and seek instead to find the means for their personal survival and reproduction from other sources (for example, welfare payments or some form of artisanal activity). Alternatively, they may attempt to struggle against the social conditions that are associated with the capitalist production process by pressing for a series of improvements in their immediate material conditions of existence (for example, higher wages, a shorter working day, job rotation, better industrial hygiene and so forth). In neither instance, however, can it be claimed that their actions are directed against the prevailing capitalist set of technical relations of production. 24 Relations such as these are not subject to modification and adjustment through struggles of this kind. Rather, they can only be expected to cease to exist in a capitalist form when the capitalist mode of production is overthrown and replaced by an entirely new structure of social and economic organization.25

It is in the light of this consideration that we can now see how Mouffe's argument is founded on a conflation of two conceptually distinct, but nonetheless closely related, issues. On the one hand, she suggests that the

24 During the era of capitalism, the only group of direct producers who can be imagined as having carried out a struggle in the manner envisioned by Mouffe was the Luddites. Their actions, however, were principally directed against the newly introduced capitalist instruments of production and not against the associated technical relations of production.

25 As Marx clearly indicates in the Critique of the Gotha Program however, even in post-capitalist society, capitalist technical relations of production will continue to exist for an indeterminate period of time. 
particular form assumed by a given set of relations in production is determined by a prevalent set of social relations of production which is itself mediated by an ongoing class struggle. Mouffe is correct to point out and emphasize the important role which these struggles have historically played in alleviating some of the worst conditions which the capitalist system has inflicted on the class of direct producers. However, what these struggles are designed to achieve (as Mouffe herself admits) is a more 'equitable' and 'just' distribution of goods within the contextual framework of a capitalist mode of production. In her view of the organizational structure governing the mode of explanatory analysis of the methodological totality, therefore, principal emphasis has come to be placed squarely on the moment of distribution.

On the other hand, (what Mouffe fails to recognize) is that struggles of this type are not sufficient in-themselves to effect any sort of fundamental alteration in the technical organization of the capitalist production process. It is precisely this technical organization of the production process, however, which gives rise to the conditions of alienation and estrangement which Marx identified as being inherent in the very structure of that process. Marx also recognized that in order to efface these conditions of alienation the class of direct producers would have to move beyond their immediate interest in alleviating their material conditions of existence and adopt, in addition, a more far-reaching and comprehensive set of objectives centered on the creation of a new form of economic organization. These new conditions of economic organization can not emerge except in the course of a long and protracted social and political struggle. What is crucial to the success of this struggle is that it is based on a recognition of the centrality of the moment of production in the analysis of the methodological totality of the social formation. Only when it is recognized that the basis of the capitalist mode of production lies in the objective structure of its production processes will it become possible to conceive, not just of a society in which there is a more 'equitable' and 'just' distribution of goods but, more fundamentally, of a society in which the enervating and debilitating conditions of alienation may possibly be alleviated. 26

\section{Mouffe and the Class Struggle}

An important corollary of the foregoing is Mouffe's argument which suggests that all attempts to maintain the thesis of the centrality of the working class in the anti-capitalist struggle must be abandoned. The principal reason for this is that such a view can only be "defended within

26 We say "possibly" because there can be no a priori guarantee that the new form of social and economic organization will not introduce new, as yet unthought of, conditions of alienation and estrangement. 
an economistic and reductionist perspective."27 More specifically, the basis of Mouffe's disagreement with the traditional Marxian position rests on an analysis of the base/superstructure model of the social formation. In her opinion this model entails a claim that is "logically incoherent." She writes:

How can it be maintained that economic agents can have interests which would be represented a posteriori at the political and ideological levels? In fact, since it is in ideology and through politics that interests are defined, that amounts to stating that interests can exist prior to the discourse in which they are formulated and articulated. This is contradictory. ${ }^{28}$

Mouffe's argument, far from establishing an alleged incoherence at the heart of the Marxian base/superstructure model, is itself based (once again) on a conflation of two closely related, but conceptually distinct, issues. That is, she fails to establish an important and central distinction between, what may be termed, the 'interests' and the 'objectives' of the class of direct producers. 29

According to Marx, the key, structural feature of a socio-economic formation, which will permit us to determine the form assumed by the class structure and the corresponding institutions of the ideological and state superstructure, is the prevailing mode of extraction of surpluslabor. 30 During the epoch of capitalism, the specific form assumed by this relationship has varied substantially. What has remained constant and pervasive throughout this epoch, however, is the existence of a wage-labor

27 Mouffe, p. 17.

28 Mouffe, p. 21.

29 For a complete and detailed criticism of Mouffe's arguments in this article see, Peter Meiksins and Ellen Meiksins Wood, 'Beyond Class? A Reply to Chantal Mouffe,' Studies in Political Economy no. 17. Fall 1975, pp. 141-165.

30 In Capital vol. 3. (Moscow: Progress Publishers, 1971) p. 791. Marx writes:

The specific economic form, in which unpaid surpluslabor is pumped out of direct producers, determines the relationship of rulers and ruled...Upon this... is founded the entire formation of the economic community... It is always the direct relationship of the owners of the conditions of production to the direct producers...which reveals the innermost secret, the hidden basis of the entire social structure. 
relationship. ${ }^{31}$ This relationship is founded in the existence of a class of direct producers who, if they wish to survive and reproduce themselves, must sell their labor-power to members of that class who own and control the social means of production. It is precisely because this relationship invariably encompasses the economic exploitation of the class of direct producers, that it becomes possible to suggest from a Marxian perspective that this class will always have a material interest in transcending this relationship.

During early periods of capitalist development this interest remained, for the most part, unarticulated and unexpressed in the public domain. Marx described this situation in his account of the emergence and development of a working class consciousness as the stage at which the direct producers formed, what he termed, a class 'in-itself. 32 This is the stage, in other words, during which the direct producers are unable to articulate a theoretical awareness of the fact of their own exploitation. As such, they are unable to formulate a viable and coherent strategy that will enable them to overcome it.

On the other hand, at periods during the relatively more advanced stage of capitalist development, it becomes possible for the class of direct producers to translate these unarticulated interests into a more or less coherent set of socio-economic and political objectives. At this stage, when the class of direct producers have become that Marx termed a class 'foritself, the previous unarticulated interest in the abolition of the conditions of capitalist exploitation comes to be expressed in the public domain through, for example, the type of program presented in the Manifesto of the Communist Party. ${ }^{33}$ Political programs of this kind map out the alternative strategies that are available to the class of direct producers as they pursue their ultimate objective, the transcendence of the wage-labor relationship.

There is no doubt that Marx seriously underestimated the wide extent of the social and political obstacles which would lie in the path of the creation of a coherent set of revolutionary aims and objectives. However, this does not mean that it is in principle inconceivable that one day these obstacles would be overcome and these aims and objectives attained. As such, the erroneous nature of Mouffe's claim that this argument is "logically incoherent" becomes evident.

In conflating the conceptually distinct notions of working class 'interests' and working class 'objectives', Mouffe is led to abandion any materialist or historical account of the creation of a revolutionary classconsciousness. Rather, she proposes an analysis of the social process in

31 See Marx's extensive discussions in the chapters entitled 'Manufacture' and 'Large-scale Industry' in Capital vol. 1.

32 See Poverty of Philosophy, in Collected Works vol. 6. p. 211.

33 See Collected Works vol. 6. pp. 508-509. 
which principal explanatory emphasis is placed on the constitutive role of 'discourse'. In good neo-Hegelian fashion, all critical analysis of the concrete, material world is replaced by an esoteric study of the ethereal and rarified realm of the 'Word'.34

Ellen Meiksins Wood's analysis in The Retreat From Class has performed an invaluable service in identifying the serious political consequences which the theory of new 'true' socialism has for the Marxian concept of epochal transition. It is important to bear in mind, however, that her analysis is primarily directed towards investigating the origin of these consequences in the attempted reformulation of the relation of determination between the economic infrastructure and the instances of the ideological and state superstructure. Put another way, she has not attempted to discern the underlying methodological or philosophical principles upon which this reformulation is based. Our aim in this paper has been to complement and extend Meiksin Wood's analysis by clarifying the nature of these deeper philosophical principles. We are now in a position to grasp that the specificity of new 'true' socialism lies, not just in a different understanding of the role of the elements of the superstructure but, more fundamentally, in a radical rejection of the primacy of the role of the economic mode of production in the analysis of the social formation.

34 This task is attempted in Chantal Mouffe and Ernesto Laclau, Hegemony and Socialist Strategy: Towards a Radical Democratic Politics (London: New Left Books, 1985). 